https://doi.org/10.52058/2786-4952 -2022-2(7)-89-100

Кравчук Неля Павлівна, кандидат педагогічних наук, доцент кафедри психології та педагогіки розвитку дитини, Уманський державний педагогічний університет імені Павла Тичини, 20300, м. Умань, вул.. Садова, 28, +380 (4744) 3-45-82, https://orcid.org/0000-0002-9420-4375

\title{
ЗАБЕЗПЕЧЕННЯ НАСТУПНОСТІ МІЖ ЗДО І НУШ В УМОВАХ РЕФОРМУВАННЯ ОСВІТИ
}

Анотація. У статті окреслено теоретико-методологічне забезпечення наступності змісту дошкільної та початкової освіти. Досліджено дві категорії понять: «наступність» та «перспективність», які у педагогічній науці розглядаються, як дві сторони одного і того ж педагогічного явища. Перспективність - це погляд знизу вгору, а наступність - погляд згори донизу. Тобто перспективність - це визначення пріоритетних ліній, підготовки дітей дошкільного віку до школи, які б максимально враховували потреби початкової школи в готовності дитини до оволодіння новою, провідною в молодшому шкільному віці навчальною діяльністю, творчим характером цієї діяльності, вільним проявом психічних новоутворень даного періоду, подальшим соціальним розвитком дітей у нових для них соціальних ролях учнів тощо.

Актуальність матеріалу, викладеного у статті, обумовлена тим, що головною умовою забезпечення наступності у вихованні і навчанні $\epsilon$ спрямованість освітнього процесу обох ланок освіти на всебічний розвиток особистості дитини.

У статті розглядаються різні погляди щодо проблеми наступності відомих науковців (К. Волинець, Ю. Волинець, М. Волчаста, С. Гончаренко, Л. Казанцева, О. Кононко, І. Крутін, Л. Крутій, О. Можаєва, Л. Парамонова, О. Половіна, О. Проскури, О. Савченко, Н. Стаднік, О. Фунтікова, І. Ліпчевська 3. Істоміна, Т. Фадєєва та ін.).

Автори визначають такі проблеми наступності закладу дошкільної освіти і Нової української школи: завищення вимог готовності дитини до шкільного навчання; недостатнє використання ігрової діяльності при переході дітей до школи; недостатня кількість психологів в освітніх установах; недостатній зв'язок програм, методів і форм навчання тощо.

Ключові слова: наступність, перспективність, Нова українська школа, заклад дошкільної освіти, учні, діти старшого дошкільного віку.

Kravchuk Nelia Pavlovna, Candidate of Pedagogic Sciences (Ph.D.), Associate Professor of the Department of Psychology and Pedagogy of Child Development Pavlo Tychyna Uman State Pedagogical University, 20300, Uman, Sadova Street, 28, +380 (4744) 3-45-82, https://orcid.org/0000-0002-9420-4375 
Журнал«Герспективитаінноваціїнауки»

(Серія«Гедагогіка», Серія«ГТихологія», Серія «Медицин»»

№2(7) 2022

\section{ENSURING CONTINUITY BETWEEN PRESCHOOL EDUCATION INSTITUTIONS AND THE NEW UKRAINIAN SCHOOL IN THE CONDITIONS OF EDUCATIONAL REFORM}

Abstract. The article outlines the theoretical and methodological support for the continuity of the content of preschool and primary education. Two categories of concepts have been studied: "continuity" and "perspective", which in pedagogical science are considered as two sides of the same pedagogical phenomenon. Perspective is a bottom-up view, and continuity is a top-down view. That is, prospects are the definition of priority lines, preparation of preschool children for school, which would take into account the needs of primary school in the child's readiness to master new, leading in primary school age educational activities, creative nature of this activity, free manifestation of mental tumors of this period. social development of children in new for them social roles of students, etc.

The relevance of the material presented in the article is due to the fact that the main condition for ensuring continuity in education and training is the focus of the educational process of both levels of education on the comprehensive development of the child's personality.

The article considers different views on the problem of continuity of famous scientists (K. Volynets, Y. Volynets, M. Volchasta, S. Goncharenko, L. Kazantseva, O. Kononko, I. Krutin, L. Krutiy, O. Mozhayeva, L. Paramonova , O. Polovina, O. Proskura, O. Savchenko, N. Stadnik, O. Funtikova, I. Lipchevska Z. Istomina, T. Fadeeva, etc.).

The authors identify the following problems of the continuity of the preschool institution and the New Ukrainian School: overestimation of the requirements of the child's readiness for school; insufficient use of play activities in the transition of children to school; insufficient number of psychologists in educational institutions; insufficient connection of programs, methods and forms of education, etc.

Key words: continuity, perspective, New Ukrainian school, preschool institution, students, older preschool children.

Постановка проблеми. Актуальність проблеми забезпечення наступності змісту дошкільної та початкової освіти набуває нині особливого значення 3 огляду на впровадження концептуальних засад реформування освіти, зокрема, Нової української школи (далі НУШ). 3 огляду на це, - необхідне створення єдиного освітнього процесу, що логічно продовжується від закладу дошкільної освіти (далі ЗДО) до школи, і допомагає досягти цілісного розвитку особистості.

Про це відзначається в нормативних документах освітнього простору України - Законах України «Про освіту», «Про дошкільну освіту», Концепції «Нова українська школа», Базовому компоненті дошкільної освіти, Державному стандарті початкової освіти та ін. Пріоритетною вважається ідея виховання людини незалежної, відповідальної, ініціативної, творчої, здатної самостійно 
будувати свою життєву та освітню траєкторії. Зокрема, у Законі «Про освіту» наголошується, що саме наступність - одна 3 необхідних умов безперервної освіти, яка певною мірою має забезпечити єдність, взаємозв'язок мети, змісту, методів, способів, організаційних форм навчання і виховання з урахуванням вікових особливостей дітей.

Ключовим напрямом державної освітньої політики $\epsilon$ забезпечення неперервності освіти, що трактується як взаємозв'язок, взаємоузгодженість і перспективність усіх іiі компонентів, зокрема, мети, змісту, методів, організаційних форм навчання на суміжних щаблях освіти. У зв'язку із цим слід прагнути до організації єдиного розвивального середовища - ЗДО та НУШ, що актуалізує вивчення даної проблеми. Адже саме зараз, коли впроваджуються засади Нової української школи, час приділити максимум уваги послідовності в умовах безперервної освіти. Усе це можливе за умови дотримання принципу наступності дошкільної та початкової освіти.

Аналіз останніх досліджень і публікацій щодо проблеми наступності в навчанні та вихованні дітей старшого дошкільного і молодшого шкільного віку відображено в працях відомих науковців (Л. Артемова, О. Біда, А. Богуш, Л. Божович, В. Бондар, 3. Борисова, М. Вашуленко, Л. Виготський, Л. Венгер, Д. Ельконін, О. Запорожець, В. Котирло, Г. Костюк, В. Кузь, Г. Люблінська, 3. Плохій, О. Проскура, Т. Тарунтаєва, О. Усова, О. Савченко, Т. Степанова, В. Сенько, С. Черемцева та ін.). Реалізація принципу наступності між дошкільною та початковою освітою вивчалася у різних таких напрямках: розкрито методологічні засади (Е. Баллер, Л. Депенчук, 3. Мукашев, І. Огородник, О. Савченко), педагогічні основи та способи забезпечення (Л. Артемова, 3. Борисова, О. Вашуленко, Т. Дябло, Л. Калмикова, О. Проскура), методичний і педагогічний аспекти (А. Богуш, Н. Кічук, В. Кузь, М. Кухта).

Мета статті - висвітлити і обгрунтувати теоретико-методологічне забезпечення наступності змісту дошкільної та початкової освіти.

Виклад основного матеріалу. Аналіз наукових праць зазначених учених свідчить про те, що сучасна постановка проблеми наступності між дошкільною та початковою ланками загальної освіти, підходи до іiі розв'язання характеризуються спрямованістю на особистісний розвиток дитини в контексті гуманістичної освітньої концепції. Як наслідок, загальні принципи, на яких нині здійснюється наступність, передбачають створення умов для цілісного психічного розвитку дитини, формування ії життєвої компетентності, спрямування на творчість і самореалізацію. Це, у першу чергу, принципи гуманізації, демократизації та диференціації, завдяки яким дошкілля і початкова школа вписуються в систему неперервної освіти.

Так, дослідниця М. Волчаста [1], виділяє такі основні ознаки впровадження наступності у освітній процес:

- послідовність і систематичність викладу навчального матеріалу, поступове зростання його складності;

- зв'язок i узгодженість змістово-методичних ліній розміщення матеріалу між різними ступенями навчання; 
Журнал«Герспективитаінновації наукиљ

(Серія«Гедагогіка», Серія«Гцихологія», Серія«Медицинв»

№2(7) 2022

- узгодженість обсягу навчального матеріалу в дошкільній і початковій освіті;

- взаємодія нових знань із раніше засвоєними i, на цій основі, досягнення учнями вищого рівня підготовки;

- використання методів і засобів, що відповідають віковим особливостям учнів на певному етапі навчання [1].

У словникових джерелах категорія «наступність» розглядається як «послідовність і системність у розміщенні навчального матеріалу, зв'язок і узгодженість ступенів і етапів навчально-виховного процесу» [2, с. 227]; як «об'єктивний необхідний зв'язок між новим і старим у процесі розвитку, що передбачає не лише ліквідацію старого, а й збереження і подальший розвиток того прогресивного й раціонального, що було досягнуто на попередніх ланках, без чого неможливий рух уперед ні в бутті, ні в пізнанні» [3, с. 327]. А дефініція «перспективність» визначається як «сприятливі умови для майбутньої діяльності когось або для наступного розвитку чогось», «передумови для успішного розвитку в майбутньому» [4, с. 653].

Спираючись на визначення науковців, можемо визначити поняття «наступність», як процес створення єдиного освітнього простору між суміжними ланками освіти, врахування вікових та психологічних особливостей дітей різних вікових періодів, підбір змісту та найбільш раціональних форм і методів навчання, з метою забезпечення гармонійного розвитку особистості на всіх рівнях освіти.

Теоретичний аналіз проблеми наступності дає підстави стверджувати, що вона має важливе значення в організації освітнього процесу в початковій освіті та $\epsilon$ умовою неперервного розвитку особистості на різних вікових етапах. Наступність - багатомірне, багатоаспектне педагогічне явище, яке розглядають, по-перше, як фактор реалізації особистісного потенціалу дитини, закономірність всебічного розвитку дитини; по-друге, як умову реалізації безперервної освіти; по-трете, як принцип навчання й виховання. Окрім цього, наступність може тлумачитися як один із компонентів теоретичних засад освітніх систем, як концептуальний підхід до вирішення освітніх завдань тощо.

Проте нині залишається відкритим для дослідження питання поєднання змісту, форм і методів забезпечення наступності дошкільної та початкової освіти в умовах реформування сучасної освіти.

Концептуальні засади реформування загальної середньої освіти «Нова українська школа» на період до 2029 року проголошують побудову освіти усіх рівнів 3 максимальним урахуванням індивідуальних фізичних, психологічних, інтелектуальних особливостей дитини кожної вікової групи. Серед ключових компонентів формули НУШ: новий зміст освіти, заснований на формуванні компетентностей, потрібних для успішної самореалізації дитини в суспільстві; наскрізний процес виховання, спрямований на формування соціальноморальних цінностей; педагогіка, що грунтується на партнерстві між учнем, учителем і батьками; дитиноцентризм, орієнтація на потреби учня в освітньому 
процесі; нова структура школи, що сприятиме засвоєнню нового змісту i формуванню життєвих компетентностей; сучасне освітнє середовище, яке забезпечить необхідні умови, засоби і технології навчання учнів, освітян i батьків у закладі освіти та поза його межами.

Тенденції розвитку дошкільної та початкової освіти в умовах реформування загальної середньої освіти на засадах Концепції Нової української школи мають багато спільного. Зокрема, гуманізм як норма поваги до особистості, доброзичливе, бережливе ставлення до дитини без спонукання i насилля; визнання самоцінності кожного вікового періоду та орієнтація на вікові особливості; урахування індивідуальних інтересів, здібностей, темпу розвитку дитини; опора на досягнення попереднього етапу розвитку; створення сприятливих умов для формування і розвитку у дитини пізнавальних, психічних процесів, належної спрямованості на активність у соціумі, конструктивних мотивів поведінки, самосвідомості, позитивної самооцінки, самоповаги та шанобливого ставлення до тих, хто ¥ї оточує; забезпечення реалізації можливостей дитини тощо.

Відтак, ми суголосні з думкою Л. Казанцевої, що «Нова українська школа це освіта нових сенсів, дитиноцентризму і поваги до кожної людини. НУШ - це цікава, практико орієнтована, безпечна і дружня до дитини школа. А для батьків вона - відкрита, чесна і націлена на співпрацю» [5].

Початкова школа грунтується на такій дошкільній підготовці: розвинені усне мовлення та уява; добре розвинені рухові та просторові координації; рухова діяльність дітей; тренованість у дошкільнят м'язів руки, добрий окомір, уміння співпрацювати у колективі, групі, здатність до самореалізації тощо.

Розглянемо напрями взаємодії ЗДО та НУШ:

1) між педагогічними колективами: обговорення та складання спільного плану заходів; взаємовідвідування уроків, занять, проведення спільних педагогічних рад, консультацій, семінарів, вивчення стану освітнього процесу в початкових класах та випускних групах ЗДО; проведення зі старшими дошкільниками екскурсії до шкільної бібліотеки, на уроки до початкових класів та циклу занять і бесід «На гостини до школи»; відвідування дошкільнятами адаптаційного курсу занять, організованих при школі. Вихователі та вчителі завдяки таким заходам збагачуються знаннями, щодо нових програм, форм i методів роботи з дітьми в ЗДО та школі;

2) між дитячим колективами: екскурсії, спільні заходи, спілкування дошкільників з учнями початкової школи, що позитивно впливає на формування товариськості, дисциплінованості, культури поведінки, почуття обов'язку та інших якостей, так необхідних майбутнім школярам;

3) спільна робота ЗДО і школи з батьками: проведення зборів батьків майбутніх першокласників, організація тематичних виставок, консультацій, спільних виховних родинних заходів; організація днів відкритих дверей для батьків у закладі загальної середньої освіти; анкетування батьків майбутніх першокласників з питань підготовки дітей до школи; відвідування свят у школі; 
організація цілеспрямованої фахової допомоги сім'ї у вирішенні ії психологопедагогічних та соціальних проблем.

Сучасні вчені (К. Волинець, Ю. Волинець, Н. Стаднік) стверджують, що «для забезпечення ефективної самореалізації дитини у процесі ії спрямування від дошкільної до початкової освіти актуалізується саме розвивальний тип взаємодії дорослого та дитини, за якого враховуються вікові індивідуальності особистості, яка зростає, що спонукає ii до творчого самовиявлення, зберігає унікальність і самобутність дошкільного дитинства, забезпечує безкризовий перехід дошкільника на позицію молодшого школяра» [6].

Зокрема, О. Можаєва зазначає, що «Одним із пріоритетних завдань співпраці ЗДО і школи - створення психолого-педагогічних умов, що забезпечують сприятливий перебіг процесу адаптації першокласників до шкільного навчання» [7]. У контексті даної співпраці простежується: наступність Державних стандартів; особистісно орієнтована модель освіти; виховання на цінностях; ігрова форма навчання; дотримання сучасних вимог до проведення занять; інтеграція освітнього процесу (планування за тематичними блоками і днями); компетентнісний підхід; орієнтація на дитину; розв'язання конфліктних ситуацій; ранкові зустрічі у колі; облаштування комфортного фізичного середовища; робота командами, групами, парами, четвірками, індивідуально; добір розвивального матеріалу (інтелектуальні карти, лепбуки, малюнки, схеми, творчі роботи); відкритість і доступність матеріалів тощо.

«Головною умовою забезпечення наступності у вихованні і навчанні, - на думку науковця I. Крутіна, - $\epsilon$ спрямованість освітнього процесу ЗДО і початкової школи на всебічний розвиток особистості дитини. 3 огляду на це необхідний зв'язок програм, методів і форм навчання в ЗДО та початкової школи. Елементи освітньої діяльності, що формуються в процесі навчання на заняттях, забезпечують успішність навчання в школі. А шкільне навчання має забезпечити взаємозв'язок, розширення, поглиблення й удосконалення отриманих у ЗДО знань, умінь і навичок. Тільки зацікавленість обох сторін, зробить перехід із ЗДО до початкової школи безболісним і успішним для дитини» [8].

Підтвердження цього знаходимо у Базовому компоненті дошкільної освіти (БКДО), в якому акцентується увага на спрямуванні зусиль батьків, педагогів, психологів на розвиток творчого потенціалу дитини, що має свої особливості у дошкільному дитинстві, на своєчасне підтримання досягнень індивідуальної своєрідності неповторного життєвого шляху дитини, забезпечення психологопедагогічного супроводу розвитку дитини у дошкільні роки. А також визначається пріоритетність компетентнісного підходу до розв'язання основних завдань дошкільної та початкової ланок освіти. Цей документ покликаний забезпечити поетапне становлення дитячої особистості, ऑiі фізичний, пізнавальний, соціальний, естетичний розвиток, набуття ним певного практичного досвіду, необхідного для використання у майбутньому житті [9].

Таким чином, забезпечується поступовий перехід від попереднього вікового періоду до нового, поєднання щойно здобутого дитиною досвіду 3 
попереднім. 3 одного боку, вона передбачає спрямованість освітньої роботи в ЗДО на вимоги, які будуть пред'явлені дітям в школі, а з іншого - на опору вчителя на досягнутий старшими дошкільниками рівень розвитку; на здобуті в ЗДО та сім'ї знання, навички і досвід дітей, на активне використання їх в освітньому процесі.

Не менш важливим аспектом підготовки дошкільників до школи є питання психологічної готовності до навчання в школі, яку розглядають педагоги, психологи, дефектологи: Л. Божович, Л. Венгер, А. Венгер, Л. Виготський, А. Запорожець, В. Мухіна, Є. Смирнова та багато інших. Авторами дається не тільки аналіз необхідних знань, навичок і умінь дитини при переході з ЗДО до школи, а й розглядаються, шляхи корекції негативних результатів і в зв'язку з цим розроблені рекомендації по роботі з дітьми та їх батьками.

Сучасні дослідниці К. Крутій, О. Фунтікова визначають дефініцію «готовність до шкільного навчання психологічна», як «комплекс психологічних якостей, що забезпечують успішність навчання дитини в школі. Містить такі компоненти: мотиваційну, вольову, інтелектуальну, особистісну, комунікативну готовність. Мотиваційна готовність - передбачає ставлення до навчальної діяльності як до суспільно важливої справи та прагнення отримати знання. Передумовою виникнення цих мотивів $є$ загальне бажання дітей вступити до школи та розвиток допитливості. Особистісна готовність - характеризується певним рівнем розвитку самосвідомості, волі та мотивів поведінки. Вольова готовність - передбачає вміння дитини діяти за зразком та здійснювати контроль шляхом зіставлення з ним як з еталоном. Інтелектуальна готовність характеризується певним рівнем розвитку пізнавальних процесів. Комунікативна готовність - передбачає певний рівень розвитку вмінь і навичок спілкування та встановлення контактів з однолітками й дорослими» $[10$, с. 56$]$.

Відтак, демонструючи готовність до школи, дошкільник завжди повинен бачити і розуміти застосування своїх знань і умінь у значущій для нього практичній діяльності. В якості такої практичної діяльності може виступати гра, спостереження та дитяче експериментування, конструктивна, музично-рухова, пізнавальна, театральна, художньо-образотворча, фізична, літературномовленнєва та трудова діяльності.

Щодо педагогів дошкільної освіти, то вони мають бути ознайомлені 3 програмою початкової школи та вводити у свої заняття навчальні елементи, які підготують дітей до 1-го класу. Вчителі початкових класів також мають знати дошкільну навчальну програму, щоб використовувати іiі складові в адаптаційний період. Таким чином, процес адаптації до школи проходить набагато легше, адже навчання відбувається в пізнавально-ігровій формі: створення лепбуків (саморобні інтерактивні книжечки, які діти створюють із захопленням); робота 3 цеглинками LEGO; створення проєктів 3 допомого LEGOSystem; «Дидактичний мультимедійний контент для початкових класів KM MEDIA Ed Profi» (мультимедійний веб-ресурс в комплекті 3 кодом доступу), де розміщені тексти для слухання і запитання до змісту творів тощо. 
Водночас недопустимою $\epsilon$ надмірна інтенсифікація інтелектуального розвитку дітей, до якої схиляються окремі педагоги ЗДО, аргументуючи це попитом батьків щодо необхідності підготовки дитини до навчання у школі. У Державному стандарті початкової освіти навчання дитини писемному мовленню (читання, письмо) передбачено в початковій школі. Неприпустимо також штучно уповільнювати індивідуальний темп розвитку дитини, не задовольняючи інтереси та потреби старших дошкільників. Доцільною $\epsilon$ організація освітнього процесу, орієнтованого на зону найближчого розвитку дитини [11].

Дослідниці О. Половіна, I. Ліпчевська зазначають, що «на сьогоднішній день у практиці ЗДО спостерігаються значні відмінності між сучасною концепцією інтелектуального розвитку дитини та практикою організації освітнього процесу. Це обумовлено низкою об'єктивних причин: недостатня освіченість та відсутність мотивації до плідної роботи практичних працівників галузі дошкільної освіти; протиріччя між сучасною концепцією інтелектуального розвитку дитини та запитом батьків на надання освітніх послуг, що не відповідають цій концепції; протиріччя між сучасною концепцією інтелектуального розвитку дитини та вимогами прихильників традиційної шкільної системи щодо інтелектуального розвитку майбутніх першокласників; недостатня матеріальна база та фінансування більшості ЗДО» [12, с. 206]. Окрім того, науковці обгрунтували іще одну важливу проблему: «Визначена у концепції НУШ методологія навчання вимагає від дитини відповідної соціальної компетенції, сформованої у дошкільні роки (рівень очікуваної компетенції визначено у БКДО, лінія «Дитина у соціумі»). Реалії сьогодення дозволяють виокремити протиріччя між очікуваним, необхідним для легкої адаптації до шкільного життя, рівнем соціального розвитку дитини та наявним рівнем соціального розвитку сучасного дошкільника» [12, с. 209].

Ми суголосні із зазначеними авторами, що формування соціальної компетентності дошкільників - важлива передумова успішної їх соціалізації у ЗДО («засвоєння та активного використання індивідом суспільного досвіду (система знань, норм, цінностей), що здійснюються в спілкуванні та повсякденній діяльності; допомагає людині функціонувати як повноправному члену суспільства») [10, с. 247]. Процес соціалізації дозволяє пройти легко соціальну адаптацію до шкільного життя («соціальне пристосування, процес або результат процесу, який передбачає гармонійне, 3 погляду індивідуальних прагнень людини, задоволення іiі потреб, створення умов для іï здорового, щасливого життя в суспільстві») [10, с. 15]. Відповідно здійснюється і соціальний розвиток дітей - це засвоєння традицій суспільства, культури, середовища, в якій малюк росте, формування його цінностей, навичок спілкування, тобто, граючи i спілкуючись 3 дорослими, дитина вчиться співіснувати 3 іншими, жити в колективі, враховувати інтереси членів цього колективу.

Разом із тим забезпечення компетентністного підходу у дошкільній та початковій ланках освіти передбачає: початкова школа забезпечує подальше 
становлення особистості дитини, зберігаючи наступність із дошкільним періодом дитинства, їі фізичний, інтелектуальний, соціальний розвиток; формує ціннісне ставлення до держави, рідного краю, української культури, здоров'я, здатність до творчого самовираження, критичного мислення; поступовий перехід від одного вікового періоду до іншого, поєднання щойно здобутого дитиною досвіду з попереднім.

Зауважимо, що реалізація наступності передбачає створення i впровадження єдиної, динамічної, перспективної системи конструктивних дій, спільних для управлінців, педагогів і батьків, спрямованих на розвиток, навчання й виховання старших дошкільників i молодших школярів, ефективність якої значною мірою залежить від впровадження в освітній процес ЗДО і початкової школи принципово новітніх способів взаємодії і зв’язку змісту, програм, методів і форм організації навчання в закладі дошкільної освіти та на початковому рівні загальної середньої освіти, підготовки педагогів, здатних вирішувати науково-методичні та практичні завдання 3 інноваційного розвитку дошкільної й початкової освіти, що відповідають реаліям не тільки сьогодення, але й майбутнього, пріоритетом яких буде формування людини нової формації.

У рамках взаємодії ЗДО та початкової школи слід враховувати: рекомендації практичного психолога; організовувати роботу консультаційного пункту та відвідування освітнього процесу; зустрічі 3 майбутнім вчителем; скласти план роботи ЗДО та НУШ з питань наступності в роботі; ознайомитись iз програмою НУШ; підготувати рекомендації для батьків.

Нині у сучасній педагогічний науці визначено пріоритетні напрямки наступності. Розглянемо їх:

перший напрямок - це узгодження мети на дошкільному i початковому шкільному рівнях. Метою дошкільної освіти є всебічний загальний розвиток дитини, визначений у відповідності 3 потенційними віковими можливостями і специфікою дитинства як самооцінного періоду життя людини.

Метою освіти в початковій школі - продовження всебічного загального розвитку дітей з урахуванням специфіки шкільного життя поряд з освоєнням найважливіших навичок у читанні, письмі, математиці та ін. Як у ЗДО, так і в школі освітній процес повинен бути спрямований на становлення особистості дитини: розвитку їі компетентності (комунікативної, інтелектуальної, фізичної), креативності, ініціативності, самостійності, відповідальності, довільності, волі і безпеки життєдіяльності, самосвідомості і самооцінки;

другий напрямок - збагачення освітнього змісту в початковій школі. На основі досліджень О. Савченко, О. Проскури, О. Кононко та ін., мова йде:

про насичення змісту навчання такими знаннями історикогеографічного i краєзнавчого характеру, які 6 максимально активізували пізнавальні інтереси дітей, відповідали б їх потребам у практичній дії i формували почуття відповідальності за найближче оточення;

про введення в педагогічний процес різних видів дитячої діяльності 
творчого характеру (самодіяльних ігор, драматизацій, технічного і художнього моделювання, експериментування, словесної творчості, музичних, танцювальних імпровізацій);

про збагачення змісту уроків естетичного циклу, художньої діяльності як одного із засобів самовираження дитини, заснованих на іiі індивідуальному емоційно-образному баченні, про прилучення до національної художньої культури шляхом відвідування музеїв, виставок, майстерень художників, концертів, театрів, бібліотек. Мета - збагатити загальнокультурний розвиток дитини, а не тільки і не стільки іiі конкретні знання, які вона повинна відтворювати за вимогою вчителя;

третій напрямок - удосконалити форми організації і методи навчання як у закладах дошкільної освіти, так і в початковій школі. Сучасні наукові дослідження Л. Парамонової, М. Поддякова, 3. Істоміної, Т. Фадєєвої вказують на необхідність:

забезпечувати рухову активність дітей у школі на уроках фізкультури, великих перервах, а також у процесі позакласної роботи;

використовувати різноманітні форми навчання, що включають специфічні види діяльності на інтегративній основі;

забезпечувати взаємозв'язок занять (фронтальних, групових) 3 повсякденним життям дітей, самостійною діяльністю (ігровою, художньою, конструктивною тощо);

використовувати в ЗДО циклічність і проектну організацію змісту навчання, що створює умови для використання самими дітьми наявного в них досвіду;

створювати розвивальне, предметне середовище як у ЗДО, так i початковій школі, функціонально моделюючий зміст дитячої діяльності;

використовувати методи, що активізують у дітей мислення, уяву, пошукову діяльність, тобто елементи проблемності у навчанні, задачі відкритого типу, що мають варіанти «правильних» рішень;

змінити форми спілкування дітей як на заняттях у ЗДО, так і на уроках у школі; забезпечити дитині можливість орієнтуватися на партнераоднолітка, взаємодіяти 3 ним і вчитися в нього (а не тільки в дорослого); підтримувати діалогічне спілкування між дітьми; визнавати право дитини на ініціативні висловлювання й аргументоване відстоювання своїх пропозицій, право на помилку. Адже саме в процесі такого спілкування діти обговорюють загальне завдання, шукають способи його вирішення, розподіляють ролі, змінюють позиції. У результаті кожен відчуває себе вмілим, знаючим, здатним впоратися з будь-яким завданням;

використовувати у початковій школі (особливо в перший рік навчання), ігрові прийоми, створювати емоційно-значимі ситуації, умови для самостійної практичної діяльності, коли діти можуть на основі наявних у них знань виявляти ініціативу, творчість, фантазію, відповідальність;

провідною в освітньому процесі як ЗДО так і початкової школи 
повинна стати діалогічна форма спілкування дорослого 3 дітьми, що сприяє розвитку в дитини активності, ініціативності, почуття власної гідності i самоповаги.

Варто відмітити, що навчання в школі вимагає пошуку нових підходів до вирішення проблеми наступності, що допомагає успішному розв'язанню завдань безперервної освіти в Україні на перших їі етапах: у ЗДО та початковій школі.

Підсумком співпраці педагогічних колективів є спільна педагогічна рада вчителів та вихователів, де аналізуються результати підготовки до школи, помилки та упущення, прогнозується подальша співпраця школи та ЗДО. Проте зусилля педагогів обох ланок освіти слід об'єднати із підтримкою батьків, щоб забезпечити успішний для кожної дитини перехід із попереднього рівня освіти на наступний.

Висновки. Щоб забезпечити реальну перспективність i наступність у роботі ЗДО та початкової школи важливо дотримуватись певних умов: співробітництво має бути довготривалим і нерозривним; робота - системною $\mathrm{i}$ плановою; завдання - комплексними та інтегрованими.

Таким чином головна умова забезпечення наступності в освіті - це тісна взаємодія педагогічних колективів, а основою такого зв'язку $\epsilon$ довіра, взаємоповага, любов до дитини, увага до іiі індивідуальних особливостей, турбота про ії гармонійний особистісний розвиток.

Перспективами подальших досліджень є обгрунтування діагностичного інструментарію щодо психологічної готовності дитини до шкільного навчання.

\section{Лimepamypa:}

1. Волчаста М. М. Наступність у вивченні геометричного матеріалу в початковій та основній школі : автореф. дис... канд. пед. наук: спец. 13.00.02. Київ, 2003. 20 с.

2. Гончаренко С. У. Український педагогічний словник. Київ : Либідь, 1997. 376 с.

3. Философский энциклопедический словарь. Ред.-сост. Е.Ф. Губский и др. М. : ИНФРА-М, 2002. 574 с.

4. Тлумачний словник Тлумачний словник української мови: Загальновживана лексика / за ред. В. С. Калашника. Харків: ФОП Співак Т. К., 2009. 960 с.

5. Казанцева Л. Наступність у роботі дошкільного закладу освіти та початкової загальноосвітньої школи у формуванні мовленнєво-комунікативних навичок дітей. Збірник наукових праць БДПУ. Бердянськ. 2002. С. 84-91.

6. Волинець К. І., Волинець Ю. О., Стаднік Н. В. Теоретичні засади наступності дошкільної і початкової освіти як проблема сучасної освіти https://www.narodnaosvita.kiev.ua/? page_id=5709 (дата звернення 10.02.2022p.)

7. Можаєва О. Формування і розвиток основних компетентностей особистості в початковій школі. Початкова освіта. 2009. №32. С. 21.

8. Крутін І. Виховуємо творчістю. Дошкільний навчальний заклад. 2008. №1. С. 18-40.

9. Базовий компонент дошкільної освіти. Нова редакція та поради для організації освітнього процесу. Київ, 2021.

10. Дошкільна освіта: словник-довідник: понад 1000 термінів, понять та назв / упор. К. Л. Крутій, О. О. Фунтікова. Запоріжжя: ТОВ «ЛІПС» ЛТД, 2010.324 с.

11. Інструктивно-методичні рекомендації щодо забезпечення наступності дошкільної та початкової освіти / Додаток до листа MOH України від 19.04.2018 № 1/9-249. URL: https://mon.gov.ua/storage/app /media/doshkilna/nastupnist/list.pdf. (дата звернення 10.02.2022p.). 
12. Половіна О.А., Ліпчевська I. Наступність дошкільної освіти та нової української школи: реалії та перспективи. Інноватика у вихованні. Збірник наукових праць. Випуск 7. Рівне, 2018. С. 203-214.

\section{References:}

1. Volchasta M. M. (2003). Nastupnist u vyvchenni heometrychnoho materialu v pochatkoviy ta osnovniy shkoli [Continuity in the study of geometric material in primary and secondary school] Extended abstract of candidates thesis. Kyyiv [in Ukrainian].

2. Honcharenko S. U. (1997) Ukrayinskyy pedahohichnyy slovnyk [Ukrainian pedagogical dictionary] Kyyiv: Lybid [in Ukrainian].

3. Filosofskiy entsiklopedicheskiy slovar. [Philosophical encyclopedic dictionary]. Red.-sost. Ye.F. Gubskiy i dr. (2002). Moskva: INFRA-M [in Russian].

4. Tlumachnyy slovnyk ukrayinskoyi movy: Zahalnovzhyvana leksyka [Explanatory dictionary Explanatory dictionary of the Ukrainian language: Common vocabulary] / za red. V. S. Kalashnyka. (2009). Kharkiv: FOP Spivak T. K. [in Ukrainian].

5. Kazantseva L. (2002). Nastupnist u roboti doshkil'noho zakladu osvity ta pochatkovoyi zahalnoosvitnoyi shkoly u formuvanni movlennyevo-komunikatyvnykh navychok ditey [Continuity in the work of preschool education and primary school in the formation of speech and communication skills of children]. Zbirnyk naukovykh prats BDPU - Collection of scientific works of the BDPU. (pp. 84-91) Berdyansk [in Ukrainian].

6. Volynets K. I., Volynets Yu. O. \& Stadnik N. V. (2019) Teoretychni zasady nastupnosti doshkilnoyi i pochatkovoyi osvity yak problema suchasnoyi osvity [Theoretical principles of continuity of preschool and primary education as a problem of modern education]. Retrieved from https://www.narodnaosvita.kiev.ua/?page_id=5709 [in Ukrainian].

7. Mozhayeva O. (2009). Formuvannya i rozvytok osnovnykh kompetentnostey osobystosti v pochatkoviy shkoli. [Mozhayeva O. Formation and development of basic personal competencies in primary school]. Pochatkova osvita - Primary education. (Vols. 32), (pp. 21- 22) [in Ukrainian].

8. Krutin I. (2008).Vykhovuyemo tvorchistyu. [Educate creativity] Doshkilnyy navchalnyy zaklad - Preschool educational institution, (pp. 18-40) [in Ukrainian].

9. Bazovyy komponent doshkilnoyi osvity. Nova redaktsiya ta porady dlya orhanizatsiyi osvitnoho protsesu [Basic component of preschool education. New edition and tips for organizing the educational process]. Kyyiv, 2021 [in Ukrainian].

10. Doshkilna osvita: slovnik-dovIdnik: ponad 1000 termInIv, ponyat ta nazv [Preschool education: vocabulary-guide: 1000 terms, understand the name], / upor. K. L. Krutiy, \& O. O. FuntIkova. Zaporizhzhia (2010): TOV «LIPS» LTD [in Ukrainian].

11. Instruktyvno-metodychni rekomendatsiyi shchodo zabezpechennya nastupnosti doshkilnoyi ta pochatkovoyi osvity / Dodatok do lysta MON Ukrayiny vid 19.04.2018 № 1/9-249 [Instructional and methodological recommendations for ensuring the continuity of preschool and primary education / Appendix to the letter of the Ministry of Education and Science of Ukraine dated 19.04.2018 № 1 / 9-249]. Retrieved from https://mon.gov.ua/storage/app/media/doshkilna/nastupnist/list.pdf [in Ukrainian].

12. Polovina O.A. \& Lipchevska I. (2018) Nastupnist doshkilnoyi osvity ta novoyi ukrayinskoyi shkoly: realiyi ta perspektyvy [Continuity of preschool education and the new Ukrainian school: realities and prospects]. Innovatyka u vykhovanni, (pp. 203-214). Rivne [in Ukrainian]. 